${ }^{1}$ Dr. Sc., Associate Professor, Head of the Electrical Machines Department, Zaporozhye National Technical University, Ukraine ${ }^{2}$ Ph. D., Associate Professor, Associate Professor of the Electrical Machines Department, Zaporozhye National Technical University, Ukraine

${ }^{3}$ Ph. D., Associate Professor, Associate Professor of the Electrical Machines Department, Zaporozhye National Technical University, Ukraine

${ }^{4}$ Senior lecturer of the Electrical Machines Department, Zaporozhye National Technical University, Ukraine

\title{
COMPUTER SIMULATION OF ELECTROMAGNETIC FIELD WITH APPLICATION THE FREQUENCY ADAPTATION METHOD
}

\begin{abstract}
Context. A modern stage of powerful radio-electronic and electrotechnical systems development, with a power more than $1 \mathrm{MW}$, imposes increased requirements to their energy equipment, uninterrupted operation and power supply reliability in various operational modes. Field simulation of such systems class is based on modern numerical realization methods of boundary value problems for Helmholtz and Maxwell equations, both in single-connected and multi-connected domains. It imposes increased requirements to resources, computer hardware speed and software computing efficiency, defining the relevance of a new mathematical apparatus development or its elaboration, including
\end{abstract} combinations of analytical and approximate numerical methods.

Objective. The purpose of work is the elaboration a new numerical realization methods of field models taking into account AC electrophysical processes with high frequency on the basis of Helmholtz equations in frequency formulations, adapted to software packages use with a free license.

Method. A new method of frequency adaptation is elaborated, which provides systems of Helmholtz equations reduction in vector magnetic potential formulations to the recurrent modified Maxwell's equations, in analogies of DC formulation, and also provides high precision and field simulation efficiency.

Results. The generalized spatial mathematical model of interrelated electromagnetic and electrothermal processes AC energy conversion in current-conducting wires of powerful radio-electronic and electrotechnical systems is offered. This model considers operational modes, nonlinear dependences of electrophysical properties in electrotechnical materials, replacement effects and outer superficial effects, self- and mutual induction. A new method of frequency adaptation is elaborated, based on Helmholtz system of equations reduction in the vector magnetic potential formulations, in frequency domain, to the recurrent modified Maxwell's equations, in analogies of DC formulation, and also provides high precision and field simulation efficiency. At numerical realization of frequency adaptation methods and finite elements, the number of freedom degrees decreases twice. It is caused by step-by-step solution the recurrent modified Maxwell's equations, in analogies of DC formulations, for real and imaginary components of electric and vector magnetic potentials.

Conclusions. The elaborated new frequency adaptation method significantly expands possibilities of production design preparation for powerful radio engineering systems. It allows using the software packages with a free license, reduces requirements to computing resources, reduces time costs and provides high precision in electromagnetic fields simulation.

Keywords: radio-electronic systems, electrotechnical systems, electromagnetic field, finite element method, frequency adaptation, field simulation, DC, AC, Helmholtz and Maxwell's equations.

\section{NOMENCLATURE}

$\mathrm{AC}$ - alternating current;

DC - direct current;

FEM - finite element method;

MBE - boundary elements methods;

$\omega$ - angular frequency;

$\Delta \omega$ - frequency step;

$i$ - component of geometric domain;

$k, n-$ interval and step of discretization;

$x, y, z$ - coordinate axes;

$V$ - electric potential;

$V_{i}$ - electric potential at $i$ component of geometric domain;

A - vector magnetic potential;

$\mathbf{A}_{x}, \mathbf{A}_{y}, \mathbf{A}_{z}-$ projection of the $\mathbf{A}$ on the axis $x, y, z$;

$\mathbf{A}_{x i}, \mathbf{A}_{y i}, \mathbf{A}_{z i}$ - projection of the $\mathbf{A}$ on the axis $x, y, z$ at $i$ component of geometric domain;

$\mathbf{A}_{\omega}, V_{\omega}-$ frequency derivatives of $\mathbf{A}$ and $V$;

$\left(\mathbf{A}_{x i}\right)_{\omega},\left(\mathbf{A}_{y i}\right)_{\omega},\left(\mathbf{A}_{z i}\right)_{\omega}-$ frequency derivatives of $\mathbf{A}_{x i}$,

$\mathbf{A}_{y i}, \mathbf{A}_{z i}$;

(C) Yarymbash D. S, Yarymbash S. T., Kotsur M. I., Litvinov D. O., 2018

DOI 10.15588/1607-3274-2018-1-8 $\sigma-$ specific electric conductivity;

$\theta$ - local temperature;

$\mu_{0}$ - vacuum permeability;

$\mu_{e}$ - equivalent relative permeability;

$\sigma_{i}$ - specific electric conductivity at $i$ component of geometric domain;

$\theta_{i}$ - local temperature at $i$ component of geometric domain;

$\mu_{e i}$ - equivalent relative permeability at $i$ component of geometric domain;

$\mathbf{i}, \mathbf{j}, \mathbf{k}-$ unit vectors;

$f$ - frequency;

H - magnetic field strength;

E - electric field strength;

$\mathbf{J}$ - current density vector;

$\mathbf{E}_{x}$ - projection of the $\mathbf{E}$ on the axis $x$;

$\mathbf{J}_{x}-$ projection of the $\mathbf{J}$ on the axis $x$;

$\Omega 1, \Omega 2$ - sections with different electrophysical properties;

$\mathbf{H}_{\Omega 1}, \mathbf{H}_{\Omega 2}$ - magnetic field strength at $\Omega 1$, $\Omega 2$ sections; 
$\mathbf{J}_{\Omega 1}, \mathbf{J}_{\Omega 2}$ - current density vector at $\Omega 1, \Omega 2$ sections; $\mathrm{C}$;

$C_{\mathrm{Re}}, C_{\mathrm{Im}}-$ real part and imaginary part of coefficient

$\delta$ - field penetration depth;

$\mathrm{c}$ - speed of light (universal physical constant);

$z_{\text {end }}$ - final thickness;

$\mathbf{E}_{\text {end }}$ - electric field strength at $z_{\text {end }}$.

\section{INTRODUCTION}

A present stage of powerful radio-electronic and electrotechnical systems development, with a capacity more than $1 \mathrm{MW}$, imposes increased requirements to their energy equipment, uninterrupted operation and power supply reliability in operating modes [1-3]. High level of competition in the international markets (in civil and defensive spheres) and also essential restrictions on mass-dimensional indicators and prices increase for electrotechnical materials both conductive, and ferromagnetic, cause relevance of creation a new domestic production at the level of the best world samples. Therefore, at the production design preparation stage of powerful radio engineering systems, it is necessary to pay great attention to auxiliary systems and structural elements, in particular, to the systems of special current-conducting wires which are carrying out a reliable power supply the basic modules and units.

Despite the large volume of the researches connected with similar systems design of current-conducting wires for other industries [4-16] to provide adaptation of their results for powerful radio engineering systems very difficult. This is due to high density of their configuration and installation, the electric power transmission with $\mathrm{AC}$ high harmonics and, as a consequence, a significant influence of proximity effects, self- and mutual induction, which are usually neglected in common industrial equipment design. The known calculation procedures and powerful systems design of special current-conducting wires, which are based on circuit simulation methods and root-mean-geometric distances [4, 5, 17-19], do not satisfy the precision requirements and reliability. Respectively, it should be compensated for, by creating and testing prototypes, and as a result, additional material expenses and financial resources, labor costs and time for production preparation, by increasing the final product cost.

Now mathematical simulation methods of electrodynamic processes in high-frequency systems on the basis of Helmholtz [20-22] equations were widely adopted, which are implemented by expensive specialized software packages (ANSYS, Comsol Multiphysics, etc.). Their use leads to the essential growth of financial costs on hardware and software production design preparation, which becomes very difficult at the existing crisis factors. In addition, the use of software with a free license, for example, FEMM, for modeling the electrophysical processes of high-frequency alternating current is limited due to the absence of specialized software modules in them. Besides, the software application with a free license, for example FEMM, for AC high frequency electrophysical processes simulation is limited due to the absence in them specialized program modules. Therefore, the elaboration problem of perspective approaches for field models numerical realization on the basis of Maxwell's equations in frequency statement should be consider relevant. These approaches expand the area of software use with a free license and adapted to production design preparation requirements for special systems of currentconducting wires of powerful power supply modules in radio engineering systems.

The purpose of the work is the elaboration a new numerical realization methods of field models taking into account AC electrophysical processes with high frequency on the basis of Helmholtz equations frequency formulations, adapted to software packages use with a free license.

To achieve this purpose, the following tasks are formulated: to elaborate new numerically-field calculations methods of interrelated electromagnetic processes during energy transmission, with AC high frequency, for special systems of current-conducting wires; to verify these methods on test mathematical models experimentally and to elaborate on this base the recommendations about their practical use.

\section{PROBLEM STATEMENT}

The electromagnetic field in geometric domains of current-conducting components and their circumambients is described by conjugate system of equations for vector magnetic potential and electric potential complex amplitudes $[7-9,11]$ :

$$
\left\{\begin{array}{l}
\nabla \times\left[\left(\mu_{0} \mu_{\mathrm{e}_{i}}\right)^{-1} \nabla \times \mathbf{A}_{i}\right]=j \omega \sigma_{i}\left(\theta_{i}\right)\left(\mathbf{A}_{i}+\nabla V_{i}\right), \\
\nabla \cdot\left[\sigma_{i}\left(\theta_{i}\right) \cdot \nabla \cdot V_{i}\right]=-j \omega \cdot \nabla \cdot\left(\sigma_{i}\left(\theta_{i}\right) \cdot \mathbf{A}_{i}\right) .
\end{array}\right.
$$

In the system of equations (1), the projections of $\mathbf{A}$ and $V$ are parametric functions of AC angular frequency $\omega$ :

$$
\left\{\begin{array}{l}
\dot{\mathbf{A}}_{i}=\mathbf{i} \cdot \dot{\mathbf{A}}_{x i}(\omega, x, y, z)+\mathbf{j} \cdot \dot{\mathbf{A}}_{y_{i}}(\omega, x, y, z)+\mathbf{k} \cdot \dot{\mathbf{A}}_{z i}(\omega, x, y, z), \\
\dot{V}_{i}=\dot{V}_{i}(\omega, x, y, z),
\end{array}\right.
$$

which have continuous derivatives in parameter $\omega$

$$
\left\{\begin{array}{l}
\left(\dot{V}_{i}\right)_{\omega}=\partial\left[\dot{V}_{i}(\omega, x, y, z)\right] / \partial \omega, \\
\left(\dot{\mathbf{A}}_{x_{i}}\right)_{\omega}=\partial\left[\dot{\mathbf{A}}_{x_{i}}(\omega, x, y, z)\right] / \partial \omega,\left(\dot{\mathbf{A}}_{y_{i}}\right)_{\omega}= \\
=\partial\left[\dot{\mathbf{A}}_{y_{i}}(\omega, x, y, z)\right] / \partial \omega,\left(\dot{\mathbf{A}}_{z i}\right)_{\omega}= \\
=\partial\left[\dot{\mathbf{A}}_{z i}(\omega, x, y, z)\right] / \partial \omega, \\
\left(\dot{\mathbf{A}}_{i}\right)_{\omega}=\mathbf{i} \cdot\left(\dot{\mathbf{A}}_{x_{i}}\right)_{\omega}+\mathbf{j} \cdot\left(\dot{\mathbf{A}}_{y_{i}}\right)_{\omega}+\mathbf{k} \cdot\left(\dot{\mathbf{A}}_{z_{i}}\right)_{\omega} .
\end{array}\right.
$$

The system of equations (1) is supplemented by magnetic and electric fields conjugation conditions at environment sections boundaries with different electrophysical properties for magnetic field strength vectors and current density in current-conducting wires [7-9]:

$$
\left\{\begin{array}{l}
\mathbf{n}_{\Omega 1, \Omega 2} \times\left(\mathbf{H}_{\Omega 1}-\mathbf{H}_{\Omega 2}\right)=0, \\
\mathbf{n}_{\Omega 1, \Omega 2} \cdot\left(\mathbf{J}_{\Omega 1}-\mathbf{J}_{\Omega 2}\right)=0,
\end{array}\right.
$$

under boundary conditions on the external shields surfaces [7-9]:

$$
\{\mathbf{A}=0, \mathbf{n} \cdot \mathbf{J}=0
$$


and on the symmetry planes [7-9]:

$$
\{\mathbf{n} \times \mathbf{H}=0, \mathbf{n} \cdot \mathbf{J}=0 .
$$

\section{REVIEW OF THE LITERATURE}

The known engineering techniques of calculation and current-carrying wires design [4-6, 17-19], based on the electrical circuit's theory, methods of generalized expressions and mean geometric distances, have essential assumptions and don't answer modern requirements of precision. In recent years, at high-frequency electromagnetic processes description, field simulation has become widespread [716]. The analytical and numerical methods [23, 24] realized on the computer can be applied to the problem formulations of electromagnetic fields simulation given above. Numerical methods are conventionally divided into three main groups [24]: integral (a boundary elements method, a secondary sources method, an integration method on field sources and a inductively connected circuits method) [23, 25, 26], differential (finite differences method and finite volumes method) [27, 28] and variation (Ritz's method, Galerkin's method, finite elements method) [29, 30, 31]. The MBE belong to the most widespread integrated methods $[26,27$, 32]. Their feature is that the integrated equation of rather unknown quantities is formulated only on the computational domain boundary. They are successfully applied to the linear partial equations solution in private derivatives of elliptic type. The FEM belongs to the variation methods based on the use of variation statements equivalent to an initial boundary-value problem [30, 33, 34]. FEM is based on the fact that for the elements into which the investigated domain is divided, an approximation of the required function is described [34, 35]. And this approximation has to provide this function's continuity throughout the definition range. FEM allow to realize rather large number of elements, when using special algorithms for systems numerical solution of algebraic equations with band matrix coefficients. The elaboration of this method became possible thanks to computer technology development and specialized software with user-friendly interfaces. They are successfully applied to the field problems solution in irregular geometrical shape domains. FEM disadvantage is the stability lowering of computational process for nonlinear frequency field models and requirements for the use of specialized expensive software [11-14] and significant computing resources [10]. Because of the essential differences in the elements geometric dimensions of current-conducting systems, in electromagnetic processes simulation, the authors [12-16] significantly simplify computational models or consider them in a plane-parallel statement $[13,14]$. Also, the community absence of approaches in describing and simulating low- and high-frequency electromagnetic processes leads to significant increase in computing and time resources that complicate the use of field calculation methods at production design preparation stages. It causes need of elaboration new approaches based both on analytical and numerical methods combination and on the frequency formulations reduction of Helmholtz problems to other types of problems.

\section{MATERIALS AND METHODS}

For synthesis a new method for system equations (1)(3) solution, it is necessary to differentiate system equations of (1) with respect to the parameter $\omega$, neglecting magnetic and electrical properties dependences of current-conducting wires materials on $\mathrm{AC}$ angular frequency $\omega$ :

$$
\left\{\begin{array}{l}
\nabla \times\left[\left(\mu_{0} \mu_{\mathrm{e}}\right)^{-1} \cdot \nabla \times\left(\dot{\mathbf{A}}_{i}\right)_{\omega}\right]=-j \sigma_{i}\left(\theta_{i}\right)\left[\dot{\mathbf{A}}_{i}+\nabla \dot{V}_{i}\right]- \\
-j \omega \sigma_{i}\left(\theta_{i}\right)\left[\left(\dot{\mathbf{A}}_{i}\right)_{\omega}+\left(\nabla \dot{V}_{i}\right)_{\omega}\right] \\
\nabla \cdot\left[\sigma_{i}\left(\theta_{i}\right) \cdot \nabla \cdot\left(\dot{V}_{i}\right)_{\omega}\right]=-j \nabla\left(\sigma_{i}\left(\theta_{i}\right) \dot{\mathbf{A}}_{i}\right)-j \omega \nabla\left(\sigma_{i}\left(\theta_{i}\right)\left(\dot{\mathbf{A}}_{i}\right)_{\omega}\right) .
\end{array}\right.
$$

Replacing continuous range domain of frequency $\omega$, by the discrete sequence $\left\{\omega_{0}=0, \omega_{1}, \ldots, \omega_{k}\right.$, $\left.\omega_{k+1}, \ldots, \omega_{n}=2 \pi \cdot f\right\}$, transform this system of the differential equations to an integrated form:

$$
\left\{\begin{array}{l}
\sum_{k=0}^{n-1} \int_{\omega_{k}}^{\omega_{k+1}}\left(\dot{V}_{i}\right)_{\omega} d \omega=\dot{V}_{i}\left(\omega_{n}, x, y, z\right)-V_{i}(0, x, y, z), \\
\sum_{k=0}^{n-1} \int_{\omega_{k}}^{\omega_{k+1}}\left(\dot{\mathbf{A}}_{x_{i}}\right)_{\omega} d \omega=\dot{\mathbf{A}}_{x_{i}}\left(\omega_{n}, x, y, z\right)-A_{x_{i}}(0, x, y, z), \\
\sum_{k=0}^{n-1} \int_{\omega_{k}}^{\omega_{k+1}}\left(\dot{\mathbf{A}}_{y_{i}}\right)_{\omega} d \omega=\dot{\mathbf{A}}_{y_{i}}\left(\omega_{n}, x, y, z\right)-A_{y_{i}}(0, x, y, z), \\
\sum_{k=0}^{n-1} \int_{\omega_{k}}^{\omega_{k+1}}\left(\dot{\mathbf{A}}_{z i}\right)_{\omega} d \omega=\dot{\mathbf{A}}_{z i}\left(\omega_{n}, x, y, z\right)-A_{z i}(0, x, y, z), \\
\mathbf{i} \cdot \sum_{k=0}^{n-1} \int_{\omega_{k}}^{\omega_{k+1}}\left(\dot{\mathbf{A}}_{x i}\right) d \omega+\mathbf{j} \cdot \sum_{k=0}^{n-1} \int_{\omega_{k}}^{\omega_{k+1}}\left(\dot{\mathbf{A}} y_{i}\right) d \omega+\mathbf{k} \cdot \sum_{k=0}^{n-1} \int_{\omega_{k}}^{\omega_{k+1}}\left(\dot{\mathbf{A}}_{z i}\right)_{\omega} d \omega= \\
=\mathbf{i} \cdot\left[\dot{\mathbf{A}}_{x_{i}}\left(\omega_{n}, x, y, z\right)-A_{x_{i}}(0, x, y, z)\right]+ \\
+\mathbf{j} \cdot\left[\dot{\mathbf{A}}_{y_{i}}\left(\omega_{n}, x, y, z\right)-A_{y_{i}}(0, x, y, z)\right]+ \\
\mathbf{k} \cdot\left[\dot{\mathbf{A}}_{z_{i}}\left(\omega_{n}, x, y, z\right)-A_{z i}(0, x, y, z)\right]
\end{array}\right.
$$

For the left parts of system ratios (8) the next designations are accepted:

$$
\left\{\begin{array}{l}
\left(\dot{V}_{i}\right)_{\omega, k}=\left(\dot{V}_{i}\left(\omega_{k}, x, y, z\right)\right)_{\omega}, \\
\left(\dot{\mathbf{A}}_{x_{i}}\right)_{\omega, k}=\left(\dot{\mathbf{A}}_{x_{i}}\left(\omega_{k}, x, y, z\right)\right)_{\omega}, \\
\left(\dot{\mathbf{A}}_{y_{i}}\right)_{\omega, k}=\left(\dot{\mathbf{A}}_{y_{i}}\left(\omega_{k}, x, y, z\right)\right)_{\omega}, \\
\left(\dot{\mathbf{A}}_{z i}\right)_{\omega, k}=\left(\dot{\mathbf{A}}_{z i}\left(\omega_{k}, x, y, z\right)\right)_{\omega} .
\end{array}\right.
$$

and the right rectangles formula [36] is applied 


$$
\left\{\begin{array}{l}
\dot{V}_{j}\left(\omega_{n}, x, y, z\right)=\sum_{k=0}^{n-1}\left(\dot{V}_{i}\right)_{\omega, k+1} \cdot\left(\omega_{k+1}-\omega_{k}\right)-V_{j}(0, x, y, z), \\
\dot{\mathbf{A}}_{x i}\left(\omega_{n}, x, y, z\right)=\sum_{k=0}^{n-1}\left(\dot{\mathbf{A}}_{x i}\right)_{\omega, k+1} \cdot\left(\omega_{k+1}-\omega_{k}\right)-A_{x i}(0, x, y, z), \\
\dot{\mathbf{A}}_{y_{i}}\left(\omega_{n}, x, y, z\right)=\sum_{k=0}^{n-1}\left(\dot{\mathbf{A}}_{y_{i}}\right)_{\omega, k+1} \cdot\left(\omega_{k+1}-\omega_{k}\right)-A_{y_{i}}(0, x, y, z), \\
\dot{\mathbf{A}}_{z i}\left(\omega_{n}, x, y, z\right)=\sum_{k=0}^{n-1}\left(\dot{\mathbf{A}}_{z i}\right)_{\omega, k+1} \cdot\left(\omega_{k+1}-\omega_{k}\right)-A_{z i}(0, x, y, z), \\
\mathbf{i} \cdot \dot{\mathbf{A}}_{x_{i}}\left(\omega_{n}, x, y, z\right)+\mathbf{j} \cdot \dot{\mathbf{A}}_{y_{i}}\left(\omega_{n}, x, y, z\right)+\mathbf{k} \cdot \dot{\mathbf{A}}_{z i}\left(\omega_{n}, x, y, z\right)=\mathbf{i} \cdot A_{x_{i}}(0, x, y, z)+ \\
+\mathbf{j} \cdot A_{y_{i}}(0, x, y, z)+\mathbf{k} \cdot A_{z i}(0, x, y, z)+\sum_{k=0}^{n-1}\left[\mathbf{i} \cdot\left(\dot{\mathbf{A}}_{x_{i}}\right)_{\omega, k+1}+\mathbf{j} \cdot\left(\dot{\mathbf{A}}_{y_{i}}\right)_{\omega, k+1}+\mathbf{k} \cdot\left(\dot{\mathbf{A}}_{y_{i}}\right)_{\omega, k+1}\right] \cdot\left(\omega_{k+1}-\omega_{k}\right)
\end{array}\right.
$$

Perform the averaging of system ratios (7) for frequency parameter change range $\left(\omega_{k} \leq \omega \leq \omega_{k+1}\right)$

$$
\begin{gathered}
\left\{\int_{\omega_{k}}^{\omega_{k+1}} \nabla \times\left[\left(\mu_{0} \mu_{\ni}\right)^{-1} \cdot \nabla \times\left(\dot{\mathbf{A}}_{i}\right)_{\omega}\right] d \omega=-j \int_{\omega_{k}}^{\omega_{k+1}}\left\{\sigma_{i}\left(\theta_{i}\right)\left[\mathbf{A}_{i}+\nabla V_{i}\right]+\right.\right. \\
\left.+\omega \sigma_{i}\left(\theta_{i}\right)\left[\mathbf{A}_{\omega_{i}}+\nabla V_{\omega_{i}}\right]\right] d \omega . \\
\left\{\int_{\omega_{k}}^{\omega_{k+1}} \nabla \cdot\left[\sigma_{i}\left(\theta_{i}\right) \cdot \nabla \cdot\left(V_{i}\right)_{\omega}\right] d \omega=\right. \\
=-j \int_{\omega_{k}}^{\omega_{k+1}}\left[\nabla\left(\sigma_{i}\left(\theta_{i}\right) \mathbf{A}_{i}\right)+\omega \nabla\left(\sigma_{i}\left(\theta_{i}\right)\left(\mathbf{A}_{i}\right)_{\omega}\right)\right] d \omega .
\end{gathered}
$$

and apply the right rectangles formulas [36] to the left parts in the systems (11), (12) and the left rectangles [36] for their right parts. By reducing them to $\left(\omega_{k+1}-\omega_{k}\right)$, there are obtained the recurrent equations of rather unknown frequency derivative potentials $\left(\dot{\mathbf{A}}_{i}\right)_{\omega, k+1}$ and $\left(\dot{V}_{i}\right)_{\omega, k+1}$ :

$$
\begin{gathered}
\left\{\nabla \times\left\lfloor\left(\mu_{0} \mu_{\ni}\right)^{-1} \cdot \nabla \times\left(\dot{\mathbf{A}}_{i}\right)_{\omega, k+1}\right]=-j \sigma_{i}\left(\theta_{i}\right)\left\{\left(\dot{\mathbf{A}}_{i}\right)_{k}+\right.\right. \\
\left.+\nabla\left(\dot{V}_{i}\right)_{k}+\omega_{k}\left[\left(\dot{\mathbf{A}}_{i}\right)_{\omega, k}+\nabla\left(\dot{V}_{i}\right)_{\omega, k}\right]\right\}, \\
\left\{\nabla \cdot\left[\sigma_{i}\left(\theta_{i}\right) \cdot \nabla \cdot\left(\dot{V}_{i}\right)_{\omega, k+1}\right]=-j\left[\nabla\left(\sigma_{i}\left(\theta_{i}\right)\left(\dot{V}_{i}\right)_{k}\right)+\right.\right. \\
\left.+\omega_{k} \nabla\left(\sigma_{i}\left(\theta_{i}\right)\left(\mathbf{A}_{i}\right)_{\omega, k}\right)\right]
\end{gathered}
$$

which allow solutions independent of each other.

If to perform summands regrouping between the left and right parts of system (13), (14) integrated equations, then it is possible to obtain the modified systems of equations in the form:

$$
\begin{gathered}
\left\{\nabla \times\left[\left(\mu_{0} \mu_{\ni}\right)^{-1} \cdot \nabla \times\left(\dot{\mathbf{A}}_{i}\right)_{\omega, k+1}\right]=-j \sigma_{i}\left(\theta_{i}\right)\left\{\left(\dot{\mathbf{A}}_{i}\right)_{k}+\right.\right. \\
\left.+\nabla\left(\dot{V}_{i}\right)_{k}+\omega_{k+1}\left[\left(\dot{\mathbf{A}}_{i}\right)_{\omega, k}+\nabla\left(\dot{V}_{i}\right)_{\omega, k}\right]\right\},
\end{gathered}
$$

$$
\begin{gathered}
\left\{\nabla \cdot\left\lfloor\sigma_{i}\left(\theta_{i}\right) \cdot \nabla \cdot\left(\dot{V}_{i}\right)_{\omega, k+1}\right\rfloor=\right. \\
\left.=-j \mid \nabla\left(\sigma_{i}\left(\theta_{i}\right)\left(\dot{V}_{i}\right)_{k}\right)+\omega_{k+1} \nabla\left(\sigma_{i}\left(\theta_{i}\right)\left(\mathbf{A}_{i}\right)_{\omega, k}\right)\right\}
\end{gathered}
$$

which differ from the recurrent equations (13), (14) by frequency parameter $\omega_{k+1}$.

In the systems of equations (13)-(16) initial approaches for vector magnetic and electric potentials are defined from independent solutions of homogeneous differential equations

$$
\left\{\begin{array}{l}
\nabla \times\left[\left(\mu_{0} \mu_{\ni i}\right)^{-1} \nabla \times \mathbf{A}_{i}\right]=0 \\
\nabla \cdot\left[\sigma_{i}\left(\theta_{i}\right) \cdot \nabla \cdot V_{i}\right]=0
\end{array}\right.
$$

and can be considered as approximations to direct current.

Initial approximation for $\left(\dot{\mathbf{A}}_{i}\right)_{\omega, 0}$ and $\left(\dot{V}_{i}\right)_{\omega, 0}$ are defined from the system of equations solutions (7), independent from each other under the condition $\omega_{0}=0$

$$
\left\{\begin{array}{l}
\nabla \times\left[\left(\mu_{0} \mu_{\ni}\right)^{-1} \cdot \nabla \times\left(\dot{\mathbf{A}}_{i}\right)_{\omega, 0}\right]=-j \sigma_{i}\left(\theta_{i}\right)\left[\left(\dot{\mathbf{A}}_{i}\right)_{0}+\nabla\left(\dot{V}_{i}\right)_{0}\right] \\
\nabla \cdot\left[\sigma_{i}\left(\theta_{i}\right) \cdot \nabla \cdot\left(\dot{V}_{i}\right)_{\omega, 0}\right]=-j \nabla\left(\sigma_{i}\left(\theta_{i}\right)\left(\dot{\mathbf{A}}_{i}\right)_{0}\right) .
\end{array}\right.
$$

Thus, by transformations (8)-(14), the system of equations in frequency formulation (1) adapts to the mathematical description and approaches for solutions in DC analogies (15)-(18). The main advantage of adapted approach should be considered possibility of independent solution the magnetic and electric fields equations with respect to frequency derivatives of vector magnetic and electric potentials on each step of frequency parameter discrete change. Initial approximations of the vector magnetic potential and electric potential are defined according to direct current. Convergence conditions of iterative process are defined by convergence conditions for Euler's method [37].

\section{EXPERIMENTS}

In data absence on the application new frequency adaptation method (7)-(18), for realization electromagnetic field problems, it is expedient to estimate its efficiency on 
the basis of a model problem, which has an exact analytical solution. For this purpose there is considered a skin-effect mathematical description in current-conducting components of waveguide system [20]. There is investigated the phenomenon of electromagnetic field localization and electric current in the domain of electrically conductive plate, $\infty$ wide and $\infty$-extended, with $z_{\text {end }}$ (fig. 1). It is accepted that current density vector will be directed along the $0 x$ axis and there is considered its projection $\dot{\mathbf{J}}_{x}, \dot{\mathbf{J}}=\mathbf{i} \dot{\mathbf{J}}_{x}(z)$, which corresponds to condition $\operatorname{div}(\dot{\mathbf{J}})=0$ and $\infty$ extended system along the $0 y$ axis.

Since the electric current is a harmonic function of time (with $\omega$ ), then, taking into account the ratio $\dot{\mathbf{E}}_{x}=\sigma \mathbf{J}_{x}=E \cdot e^{j \varphi}$, it suffices to consider Helmholtz equation with respect to electric field strength amplitude [20]:

$$
\frac{d^{2} E}{d z^{2}}-j \frac{4 \pi \mu_{0} \sigma}{c^{2}} E=0 .
$$

with boundary conditions in the form:

$$
E(0)=E_{0}, E\left(z_{\text {end }}\right)=E_{\text {end }},
$$

General solution of equation (19) has the form [20]:

$$
E(z)=C_{\operatorname{Re}} \cdot e^{i \sqrt{-i 4 \pi \sigma \mu \omega / c^{2}}}+C_{\operatorname{Im}} \cdot e^{-i \sqrt{-i 4 \pi \sigma \mu \omega / c^{2}}} .
$$

Taking into account the expression for skin-effect layer thickness

$$
\delta=c / \sqrt{2 \pi \sigma \mu \omega}
$$

expression (21) can be transformed to the next form:

$$
E(z)=C_{\operatorname{Re}} \cdot e^{-i(1-i) z / \delta}+C_{\operatorname{Im}} \cdot e^{i(1-i) z / \delta} .
$$

If to enter designation $\widetilde{E}=E(z) / E_{\text {end }}$, then, satisfying expression (23) to boundary conditions (20), we obtain an analytical solution that describes distribution of the intensity complex amplitude $\widetilde{E}$ in electrically conductive domain (Fig. 1):

$$
\widetilde{E}(z, \delta)=\frac{\left(1-e^{\left(z_{\text {end }}(1+i)\right) / \delta}\right) \cdot e^{-i(1-i) z / \delta}+\left(e^{\left(z_{\text {end }}(-1-i)\right) / \delta}-1\right) \cdot e^{i(1-i) z / \delta}}{e^{\left(z_{\text {end }}(-1-i)\right) / \delta}-e^{\left(z_{\text {end }}(1+i)\right) / \delta}} .
$$

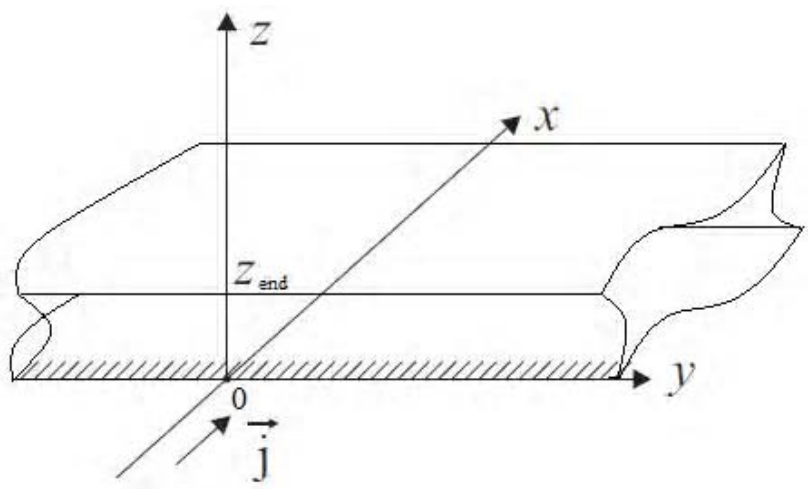

Figure 1 - Skin-effect simulation domain in current-conducting wire
By frequency adaptation method for a frequency step equal to $\Delta \omega=\omega$, the approximate solution of equation (19) with boundary conditions (20) will have the next form:

$$
\widetilde{E}_{\Delta \omega=\omega}(z, \delta) \approx 1+\frac{\sqrt{2}}{6 \delta^{4}} z \cdot\left(z_{\text {end }} \cdot z^{2}-\frac{z_{\text {end }}^{3}+z^{3}}{2}\right)+i \frac{\sqrt{2}}{2 \delta^{2}} z \cdot\left(z-z_{\text {end }}\right) .
$$

For analysis of approximate solution precision, obtained by frequency adaptation method, there were carried out electric field strength calculations for a planar conductor, the thickness of which changed in a range $1.4 \cdot \delta \leq z_{\text {end }} \leq 2.0 \cdot \delta$ with $\Delta z_{\text {end }}=0.2$ step and there was estimated the approximate solution error (25) with respect to exact solution (24). A typical feature of frequency adaptation method is the even number of iterations. On odd iterations, the imaginary components of the solution are specified, and on even ones, the real components. At the same time the number of iterations for studied model doesn't exceed 4 .

\section{RESULTS}

Results of numerical experiments for a research of approximate solutions precision, obtained by an analytical method and a new frequency adaptation method are presented in Fig. 2. According to the exact solution, the nonlinear character of the field strength distribution is determined by the depth of its penetration into electroconductive environment, mainly by AC frequency. At electroconductive layer thickness $1.4 \cdot \delta \leq z_{\text {end }} \leq 1.8 \cdot \delta$ the distribution will have a parabolic form. Comparison of exact solutions the system of equations (1) and calculations by a new frequency adaptation method (25), taking into account $\Delta \omega=\omega$, confirms that the error of this method is lower than $0,6 \%$ for parabolic form of field strength distribution in current-carrying components domain of current-conducting systems (Fig. 2a).

For exact solution, at $z_{\text {end }} \geq 2.0 \cdot \delta$, the parabolic form of field strength distribution is transformed into a flattened form (Fig. 2), and the error of frequency adaptation method increases to $5.1 \%$ due to the effect of the "false" local convexity on the symmetry axis of current-conducting wires. This negative effect is easily compensated by a step reduction of frequency adaptation to $\Delta \omega=0.5 \cdot \omega$, and by increasing the number of iterations up to 4 , at the same time the error decreases to $1.2 \%$ in comparison with exact solution (Fig. $2 b)$. It confirms high precision of the offered frequency adaptation method, which can be also realized in structure of application programs packages for stationary field simulation, as a rule, having a free license (for example, FEMM).

For current-conducting wires with a rectangular plan configuration, field calculations were performed in Comsol Multiphysics software structure for frequency model (1)(6) and in the FEMM software structure for frequency adaptation model (18). Field calculations in Comsol Multiphysics and FEMM structures used triangular finite elements, the number of which was 55264. When comparing the arrays of local values for magnetic field strength module, the relative discrepancy deviation for these methods did not exceed $1.24 \%$ for $\Delta \omega=\omega$ and $0.75 \% \Delta \omega=0,5 \cdot \omega$. As 


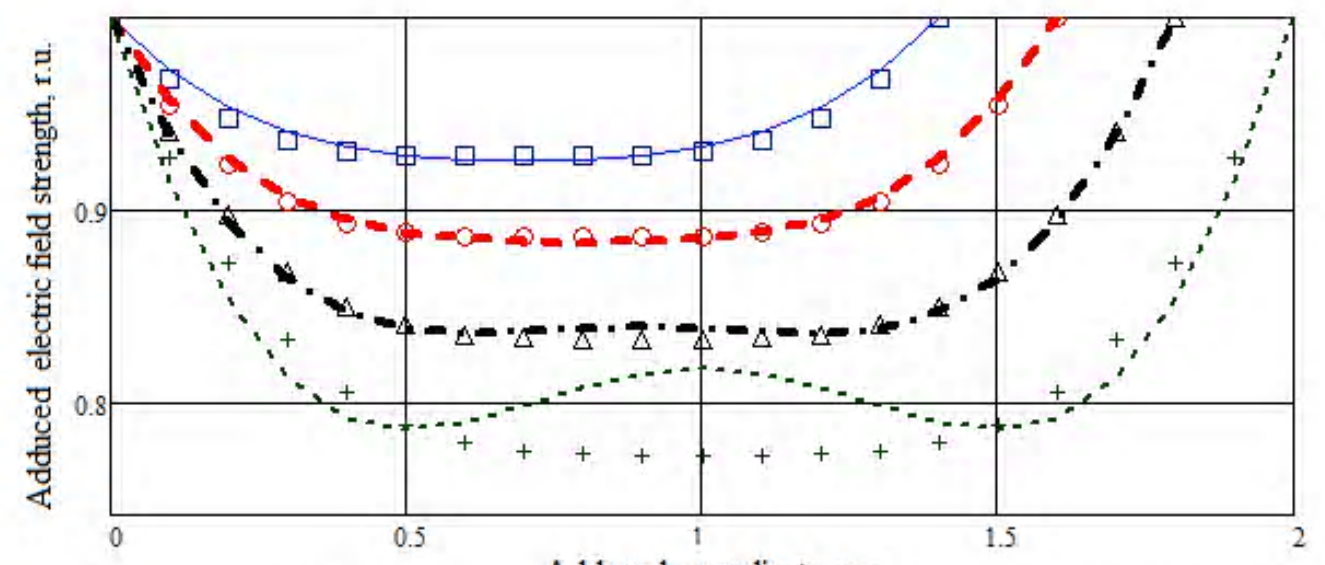

Adduced coordinate, r.u.
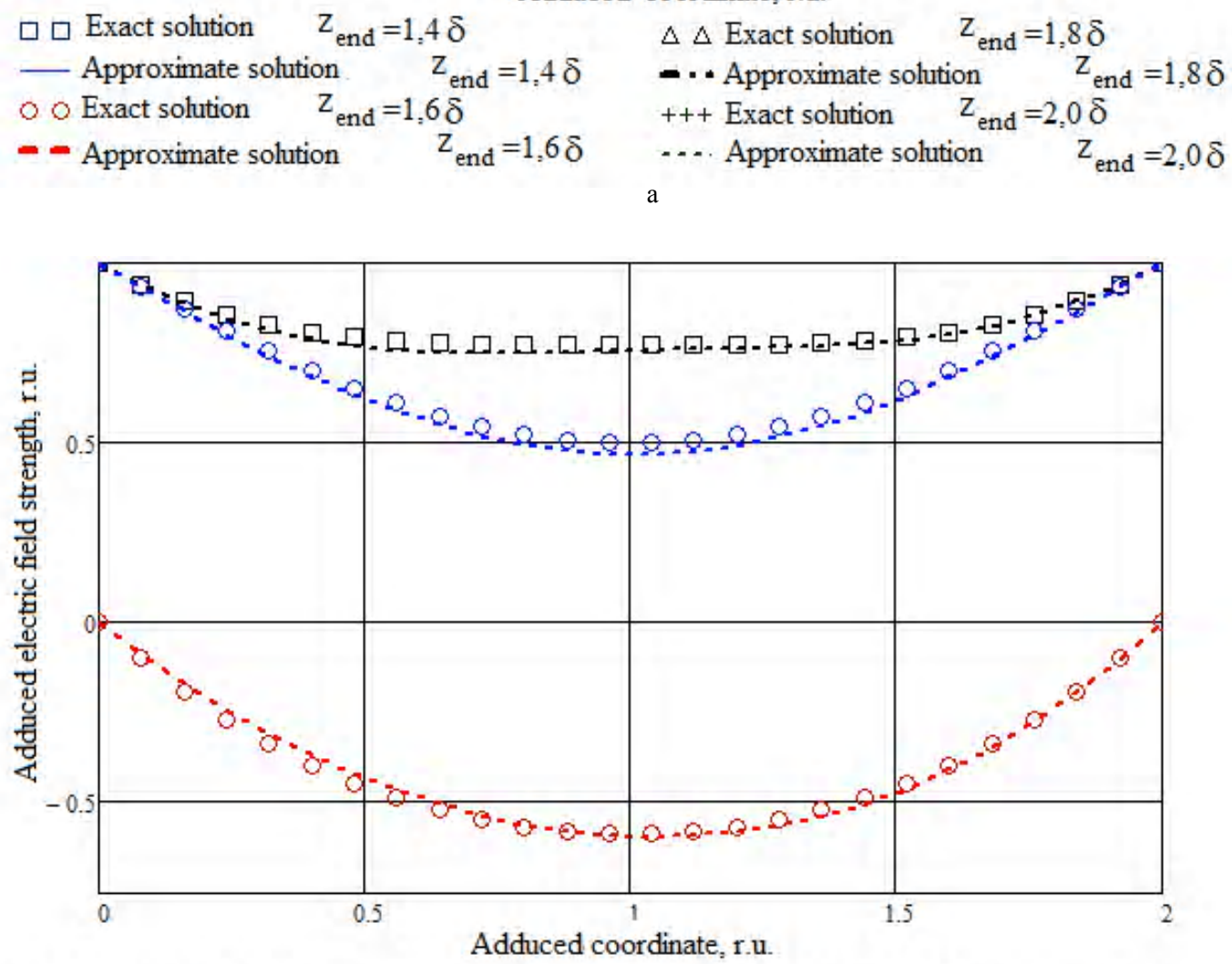

$\square \square$ Exact solution module $\mathrm{z}_{\text {end }}=2.0 \delta$

$\circ$ Real part of exact solution $Z_{\text {end }}=2,0 \delta$

0 Imaginary part of exact solution $\mathrm{Z}_{\text {end }}=2,0 \delta$
-.. Approximate solution module $\mathrm{Z}_{\text {end }}=2,0 \delta$

- . Real part of approximate solution $\mathrm{Z}$ end $=2,0 \delta$

.. - Imaginary part of approximate solution $z_{\text {end }}=2,0 \delta$

Figure 2 - The exact (24) and approximate (25) solutions comparison of Helmholtz equation (14):

$$
\mathrm{a}-\text { for } \Delta \omega=\omega ; \mathrm{b}-\text { for } \Delta \omega=0.5 \cdot \omega
$$

the number of freedom degrees on each frequency adaptation step decreases twice, time consumption for numerical realization the frequency adaptation stationary model (18) decrease by $2.4-2.8$ times at $\Delta \omega=\omega$. At $\Delta \omega=0.5 \cdot \omega$ time consumption is decreased by $1.12-1.18$ times in comparison with numerical realization frequency model (1)-(3).

\section{DISCUSSION}

Thus, the frequency adaptation method has a simple numerical implementation and doesn't require the use of specialized commercial software. This method can be used in conjunction with final elements method and can be realized in the FEMM structure. At the joint application the frequency adaptation methods and final elements method, the numerical realization efficiency is caused by reduction the problem dimension on each step in frequency twice. It's provided by step-by-step realization the recurrent equations (18) both for the real, and for imaginary components of potentials. Error's growth of the frequency adaptation method at $\mathrm{z}_{\text {end }} \geq 2.0 \cdot \delta$ can be compensated by decreasing 
the frequency step from $\Delta \omega=\omega$ to $\Delta \omega=0,5 \cdot \omega$. The frequency adaptation method's error for problem solution of AC electric field in a one-dimensional statement doesn't exceed $0.6 \%$ for $\Delta \omega=\omega$, in $1.4 \cdot \delta \leq z_{\text {end }} \leq 1.8 \cdot$ range, and $1.2 \%$ for $\Delta \omega=0.5 \cdot \omega$, in $1.8 \cdot \delta \leq z_{\text {end }} \leq 2.0 \cdot \delta$ range. Thus, the frequency adaptation method provides good computational accuracy for engineering calculations. This method can be used in problems of calculation and analysis of electromagnetic fields in one-dimensional, twodimensional and three-dimensional formulations. Numerical realization data, in Comsol Multiphysics and FEMM structures for frequency adaptation to stationary field models, correspond with high precision to numerical realization data for frequency field models, but the time consumption are reduced from 1.12 to 2.8 .

\section{CONCLUSIONS}

A new method of frequency adaptation is elaborated, which provides systems of Helmholtz equations reduction in frequency domain to the recurrent Maxwell's equations in DC analogies, high precision and field simulation efficiency. At the joint realization the frequency adaptation methods and final elements method the number of freedom degree decreases twice, which is provided by step-by-step realization the recurrent modified Maxwell's equations in DC analogies, both for the real, and for imaginary components of the electrical and vector magnetic potentials. The frequency adaptation method's error for problem solution of AC electric field in a one-dimensional statement doesn't exceed $0.6 \%$ for $\Delta \omega=\omega$, in $1.4 \cdot \delta \leq z_{\text {end }} \leq 1.8 \cdot \delta$ range, and $1.2 \%$ for $\Delta \omega=0.5 \cdot \omega$, in $1.8 \cdot \delta \leq z_{\text {end }} \leq 2.0 \cdot \delta$ range. At calculating the plane-parallel electromagnetic field for current-conducting components of current carrying systems the frequency adaptation method's error doesn't exceed $1.24 \%$, and time consumption are reduced from 1.12 to 2.8 .

The elaborated frequency adaptation method significantly expands possibilities of production design preparation for the powerful radio engineering systems, allows to use software packages with a free license, reduces requirements to computing resources, reduces time consumption and provides high precision of electromagnetic fields simulation.

\section{REFERENCES}

1. Skolnik M. Radar Handbook / M. Skolnik. - New York : The McGraw-Hill, 2008. - 1350 p.

2. Дудник П. И. Многофункциональные радиолокационные системы : учеб. пособие для вузов / П. И. Дудник, А. Р. Ильчук, Б. Г. Татарский ; под ред. Б. Г. Татарского. - М. : Дрофа, 2007. - 283 с

3. Высокоточные системы самонаведения: расчет и проектирование. Вычислительный эксперимент / К. А. Пупков, Н. Д. Егупов, Л. В. Колесников, и др. - М. : Физматлит, 2011. $512 \mathrm{c}$.

4. Данцис Я. Б. Короткие сети и электрические параметры дуговых электропечей / Я. Б. Данцис, Г. М. Жилов. - М. : Металлургия, 1987. - 320 с.

5. Бида В. В. К расчету токоведущих систем, образованных контурами сложной геометрии / В. В. Бида, Ю. М. Васецкий, С. В. Захарченко // Известия ВУЗов. Электромеханика. - 1990. № 6. - C. 19-27.
6. Розенберг В. Л. Метод расчета индуктивностей токопроводящей системы «керн графитировочной печи - боковые шинопакеты» / В. Л. Розенберг, В. А. Сычев, Я. В. Метелица // Автоматизация энергосистем и энергоустановок промышленных предприятий : сб. научн. тр. - Челябинск : ЧПИ, 1985. C. $15-18$.

7. Ярымбаш Д.С. Исследование электромагнитных и термоэлектрических процессов в печах графитации переменного и постоянного тока / Д. С. Ярымбаш // Науковий вісник НГУ 2015. - № 3. - C. 95-102.

8. Yarymbash D. S. On specific features of modeling electromagnetic field in the connection area of side busbar packages to graphitization furnace current leads / D.S. Yarymbash, A.M. Oleinikov // Russian Electrical Engineering. - 2015. - Vol. 86, Issue 2. - P. 86-92. DOI: http://dx.doi.org/10.3103/ S1068371215020121.

9. Ярымбаш Д. С. Идентификация электрических параметров шихтованных шинных пакетов мощных коротких сетей / Д. С. Ярымбаш, С. Т. Ярымбаш, И. М. Килимник // Электротехника и электроэнергетика. - 2012. - № 2. - С. 55-61. DOI: http://dx.doi.org/10.15588/1607-6761-2012-2-10

10. Ярымбаш Д. С. Идентификация электрических параметров печной петли мощных печей графитации / Д. С. Ярымбаш // Электротехника и электромеханика. - 2012. - № 1. - С. 49-54.

11. A new simulation approach of the electromagnetic fields in electrical machines / [D. Yarymbash, M. Kotsur, S. Subbotin, A. Oliinyk] // IEEE: The International Conference on Information and Digital Technologies - 2017. - Slovakia, Zilina. - P. 452457. DOI: 10.1109/DT.2017.8024332.

12. Experience and modern technology of the ore-thermal furnace short network designing / [A. I. Aliferov, R. A. Bikeev, L. P. Goreva, V. Zakharchuk] // 11 International forum on strategic technology (IFOST 2016) : proc., Novosibirsk, 1-3 June 2016. Novosibirsk : NSTU, 2016. - Pt. 2. - P. 124-126. ISBN 978-15090-0853-7. DOI: $10.1109 /$ IFOST.2016.7884207

13. Serikov V. Active power losses in pressure rings for contact shoes of ore-thermal furnace/ V. Serikov, D. Vlasov, L. Goreva // Applied Mechanics and Materials. - 2015. - Vol. 698 : Electrical Engineering, Energy, Mechanical Engineering, EEM 2014. - P. 57-60. DOI: 10.4028/www.scientific.net/AMM.698.57

14. Goreva L. Investigation of electrical parameters of interleaved conductors' packages in high power electrotechnological installations / L. Goreva, D. Vlasov, M. S. Shvetsova // Applied Mechanics and Materials. - 2015. - Vol. 792 : Electrical Engineering, Electrotechnology, Energy, EEE 2015. - P. 495498. DOI: 10.4028/www.scientific.net/AMM.792.495

15. Ore-thermal furnaces secondary circuit parameters optimization / A. I. Aliferov, L. P. Goreva, R. A. Bikeev et al. // The 8 international forum on strategic technologies (IFOST 2013) : proc., Mongolia, Ulaanbaatar, 28 June - 1 July 2013. Ulaanbaatar, 2013. - Vol. 1. - P. 283-285. DOI: 10.4028/ www.scientific.net/AMM.698.35.

16. Ferromagnetic conductors electric resistances investigation under electrocontact heating / A. I. Aliferov, R. A. Bikeev, D. S. Vlasov et al. // International conference on heating by electromagnetic sources, HES-2013: induction, dielectric and microwaves, conduction \& electromagnetic processing : [proc.], Italy, Padua, 21-24 May, 2013. - Padua, 2013. - P. 457-461.

17. Arc-Furnace model for the study of Flicker Compensation in Electrical Networks / G. G. Montanari, M. Loggini, A. Cavallini et al. // IEEE Transactions on Power Delivery. - 1994. - Vol. 9, No. 4. - P. 2026-2036. DOI: 10.1109/61.329535.

18. Development of Enhanced Electric Arc Furnace Models for Transient Analysis / G. Jang, W. Wang, G. I. Heydt et al. // Electric Power Components and Systems. - 2001. - Vol. 29, No. 11. P. 1060-1073. DOI: 10.1080/153250001753239257. 
19.Panoiu M. Experimental Research Concerning the Electromagnetic Pollution Generated by the 3-Phase Electric Power Supply Networks / M. Panoiu, C. Panoiu, I. Sora // Acta Electrotehnica. - 2006. - Vol. 47, No. 2. - P. 102-112.

20. Запрягаев С. А. Электродинамика / С. А. Запрягаев. - Воронеж : Изд-во Воронеж. гос. ун-та, 2005. - 536 с.

21. Ильинский А. С. Математические модели электродинамики / А. С. Ильинский, В. В. Кравцов, А. Г. Свешников. - М. : Высшая школа, 1991. - 222 с.

22. Taflove A. Computational Electrodynamics: The Finitedifference Time-domain Method / A. Taflove, S. C. Hagness Artech House, 2005. - 852 p. ISBN 978-1-58053-832-9.

23. Амосов А. А. Вычислительные методы для инженеров / Амосов А. А. - М. : Энергия, 1994. - 284 с.

24. Рояк М. Э. Сеточные методы решения краевых задач математической физики: учеб. пособие / М. Э. Рояк, Ю. Г. Соловейчик, Э. П. Шурина. - Новосибирск : Изд-во НГТУ, 1998. - 120 с.

25. Кошляков Н. С. Уравнения в частных производных математической физики / Н. С. Кошляков, Э. Б. Глинер, М. М. Смирнов. - М. : Высшая школа, 1970. - $710 \mathrm{c.}$

26. Самарский А. А. Численные методы / А. А. Самарский, В. А. Гулин. - М. : Наука, 1989. -430 с.

27. Абаффи Й. Математические методы для решения линейных и нелинейных уравнений / Й. Абаффи, Э. Спедикато. - М. : Энергия, 1996. - 287 c.

28. Yee K. S. Numerical solution of initial boundary value problems involving Maxwell's equations in isotropic media / K. S. Yee //
IEEE Trans. Antennas Propagat. - 1996. - Vol. 14. - P. 302 307. DOI: $10.1109 /$ tap.1966.1138693.

29. Глазунов Ю. Т. Вариационные методы / Ю. Т. Глазунов. М. : Регулярная и хаотическая динамика, Институт компьютерных исследований, 2006. - 472 с.

30. Никольский В. В. Вариационные методы для внутренних задач электродинамики / В. В. Никольский. - М. : Наука, 1967. $460 \mathrm{c}$.

31. Ректорис К. Вариационные методы в математической физике и технике / К. Ректорис. - М. : Мир, 1985. - 589 с.

32. Бреббия К. Методы граничных элементов / К. Бреббия, Ж. Теллес, Л. Вроубел. - М. : Мир, 1987. - 524 с.

33. Лаевский Ю. М. Метод конечных элементов (основы теории, задачи) / Ю. М. Лаевский. - Новосибирск : Новосиб. гос. унт, 1999. - $166 \mathrm{c}$.

34. Стренг Г. Теория метода конечных элементов / Г. Стренг, Дж. Фикс. - М. : Мир, 1977. - 350 с.

35. Астахов В. И. Математическое моделирование инженерных задач в электротехнике: учебное пособие / В. И. Астахов. Новочеркасск : НГТУ, 1994. - 192 с.

36. Самарский А. А. Введение в численные методы: учебное пособие для вузов / А. А. Самарский. - [3-е изд.]- СПб. : Издательство «Лань», 2005. - 288 с

37. Бабенко К. И. Основы численного анализа / К. И. Бабенко. М. : Наука, 1986. - 374 с.

Article was submitted 06.11.2017. After revision 22.12.2017.

Ярымбаш Д. С. ${ }^{1}$, Ярымбаш С. Т. ${ }^{2}$, Коцур М. И.. ${ }^{3}$ Литвинов Д. А. ${ }^{4}$

'Д-р техн. наук, доцент, заведующий кафедрой электрических машин Запорожского национального технического университета, Украина

${ }^{2}$ Канд. техн. наук, доцент, доцент кафедры электрических машин Запорожского национального технического университета, Украина

${ }^{3}$ Канд. техн. наук, доцент, доцент кафедры электрических машин Запорожского национального технического университета, Украина

${ }^{4}$ Старший преподаватель кафедры электрических машин Запорожского национального технического университета, Украина

КОМПЬЮТЕРНОЕ МОДЕЛИРОВАНИЕ ЭЛЕКТРОМАГНИТНОГО ПОЛЯ С ПРИМЕНЕНИЕМ МЕТОДА ЧАСТОТНОЙ АДАПТАЦИИ

Актуальность. Современный этап развития мощных радиоэлектронных и электротехнических систем с мощностью более 1 МВт предъявляет повышенные требования к их энергооснащенности, бесперебойности и надежности энергообеспечения в различных эксплуатационных режимах. Полевое моделирование такого класса систем базируется на современных методах численной реализации краевых задач для уравнений Гельмгольца и Максвелла как в односвязных, так и в многосвязных областях. Это предъявляет повышенные требования к ресурсам, быстродействию средств вычислительной техники и к вычислительной эффективности программного обеспечения, определяя актуальность разработки нового или развитие используемого математического аппарата, в том числе комбинаций аналитических и приближенных численных методов.

Целью работы является разработка новых методов численной реализации полевых моделей электрофизических процессов переменного тока высокой частоты на основе частотных формулировок уравнений Гельмгольца, адаптированных к использованию пакетов программ со свободной лицензией.

Метод. Разработан новый метод частотной адаптации, обеспечивающий редукцию систем уравнений Гельмгольца в формулировках векторного магнитного потенциала к рекуррентным модифицированным уравнениям Максвелла в аналогиях формулировок постоянного тока, высокую точность и эффективность полевого моделирования.

Результаты. Предложена обобщенная пространственная математическая модель взаимосвязанных электромагнитных процессов преобразования энергии переменного тока в токопроводах мощных радиоэлектронных и электротехнических систем, которая учитывает эксплуатационные режимы, нелинейные зависимости электрофизических свойств электротехнических материалов, эффекты вытеснения и внешние поверхностные эффекты, само и взаимоиндукцию. Разработан новый метод частотной адаптации, основанный на редукции систем уравнений Гельмгольца в формулировках векторного магнитного потенциала в частотной области к рекуррентным модифицированным уравнениям Максвелла в аналогиях постоянного тока, обеспечивающий высокую точность и вычислительную эффективность. При численной реализации методов частотной адаптации и конечных элементов число степеней свободы уменьшается в два раза, что обусловлено поэтапным решением рекуррентных модифицированных уравнений Максвелла в аналогиях формулировок постоянного тока для действительных и мнимых составляющих электрических и векторных магнитных потенциалов.

Выводы. Разработанный новый метод частотной адаптации существенно расширяет возможности конструкторской подготовки производства мощных радиоэлектронных и электротехнических систем систем, позволяет использовать пакеты программ со свободной лицензией, снижает требования к вычислительным ресурсам, сокращает временные затраты и обеспечивает высокую точность моделирования электромагнитных полей.

Ключевые слова: радиоэлектронные системы, электротехнические системы, электромагнитное поле, метод конечных элементов, частотная адаптация, полевое моделирование, уравнения Гельмгольца и Максвелла. 
Яримбаш Д. С. ${ }^{1}$, Яримбаш С. Т. ${ }^{2}$, Коцур М. І. ${ }^{3}$, Літвінов Д. О. ${ }^{4}$

'Д-р техн. наук, доцент, завідувач кафедри електричних машин Запорізького національного технічного університету, Україна

${ }^{2}$ Канд. техн. наук, доцент, доцент кафедри електричних машин Запорізького національного технічного університету, Україна

${ }^{3}$ Канд. техн. наук, доцент, доцент кафедри електричних машин Запорізького національного технічного університету, Україна

${ }^{4}$ Старший викладач кафедри електричних машин Запорізького національного технічного університету, Україна

КОМП'ЮТЕРНЕ МОДЕЛЮВАННЯ ЕЛЕКТРОМАГНІТНОГО ПОЛЯ 3 ВИКОРИСТАННЯМ МЕТОДУ ЧАСТОТНОї
АДАПТАЦЇ
АКТУальність. Сучасний етап розвитку потужних радіоелектронних і електротехнічних систем з потужністю понад 1 МВт висуває підвищені вимоги до їх енергоозброєння, безперебійності та надійності енергозабезпечення в різних експлуатаційних режимах. Польове моделювання такого класу систем базується на сучасних методах чисельної реалізації крайових задач для рівнянь Гельмгольца та Максвелла як в однозв'язних, так і в багатозв'язних областях. Це висуває підвищені вимоги до ресурсів, швидкодії засобів обчислювальної техніки та до обчислювальної ефективності програмного забезпечення, визначаючи актуальність розробки нового або розвиток існуючого математичного апарату, в тому числі комбінацій аналітичних і наближених чисельних методів.

Метою роботи $\epsilon$ розробка нових методів чисельної реалізації польових моделей електрофізичних процесів змінного струму високої частоти на основі частотних формулювань рівнянь Гельмгольца, адаптованих до використання пакетів програм 3 вільною ліцензією.

Метод. Розроблено новий метод частотної адаптації, що забезпечує редукцію систем рівнянь Гельмгольца в формулюваннях векторного магнітного потенціалу до рекурентних модифікованим рівнянням Максвелла в аналогіях формулювань постійного струму, високу точність і ефективність польового моделювання.

Результати. Запропоновано узагальнену просторову математичну модель взаємозалежних електромагнітних процесів перетворення енергії змінного струму в струмопровідах потужних радіоелектронних та електротехнічних систем, яка враховує експлуатаційні режими, нелінійні залежності електрофізичних властивостей електротехнічних матеріалів, ефекти витіснення і зовнішні поверхневі ефекти, само- та взаємоіндукції. Розроблено новий метод частотної адаптації, заснований на редукції систем рівнянь Гельмгольца в формулюваннях векторного магнітного потенціалу в частотній області до рекурентних модифікованим рівнянням Максвелла в аналогіях постійного струму, що забезпечує високу точність і обчислювальну ефективність. При чисельній реалізації методів частотної адаптації і скінчених елементів число ступенів свободи зменшується в два рази, що зумовлено поетапним рішенням рекурентних модифікованих рівнянь Максвелла в аналогіях формулювань постійного струму для дійсних і уявних складових електричних і векторних магнітних потенціалів.

Висновки. Розроблений новий метод частотної адаптації істотно розширює можливості конструкторської підготовки виробництва потужних радіоелектронних та електротехнічних систем, дозволяє використовувати пакети програм з вільною ліцензією, знижує вимоги до обчислювальних ресурсів, скорочує витрати часу і забезпечує високу точність моделювання електромагнітних полів.

Ключові слова: радіоелектронні системи, електротехнічні системи, електромагнітне поле, метод скінчених елементів, частотна адаптація, польове моделювання, рівняння Гельмгольца і Максвелла.

\section{REFERENCES}

1. Skolnik M. Radar Handbook. New York, The McGraw-Hill, 2008, $1350 \mathrm{p}$.

2. Dudnik P. I., Il'chuk A. R., Tatarskij B. G. Mnogofunkcional'nye radiolokacionnye sistemy : ucheb. posobie dlja vuzov. Moscow, Drofa, 2007, 283 p.

3. Pupkov K. A., Egupov N. D., Kolesnikov L. V. et al. Vysokotochnye sistemy samonavedenija: raschet i proektirovanie. Vychislitel'nyj jeksperiment. Moscow, Fizmatlit, 2011, 512 p.

4. Dancis Ja. B., Zhilov G. M. Korotkie seti i jelektricheskie parametry dugovyh jelektropechej. Moscow, Metallurgija, 1987, $320 \mathrm{p}$.

5. Bida V. V., Vaseckij Ju. M., Zaharchenko S. V. K raschetu tokovedushhih sistem, obrazovannyh konturami slozhnoj geometrii, Izvestija VUZov. Jelektromehanika, 1990, No. 6, pp. 19-27.

6. Rozenberg V. L., Sychev V. A., Metelica Ja. V. Metod rascheta induktivnostej tokoprovodjashhej sistemy "kern grafitirovochnoj pechi - bokovye shinopakety", Avtomatizacija jenergosistem i jenergoustanovok promyshlennyh predprijatij : Sb. nauchn. tr, Cheljabinsk, ChPI, 1985, pp. 15-18.

7. Yarymbash, D. S. The research of electromagnetic and thermoelectric processes in the AC and DC graphitization furnaces, Naukovyi Visnyk Natsionalnoho Hirnychoho Universytetu, 2015, No. 3, pp. 95-102.

8. Yarymbash D. S., Oleinikov A. M. On specific features of modeling electromagnetic field in the connection area of side busbar packages to graphitization furnace current leads, Russian Electrical Engineering, 2015, Vol. 86, Issue 2, pp. 86-92. DOI: http:// dx.doi.org/10.3103/S1068371215020121.

9. Yarymbash D. S., Yarymbash, S. T. and Kylymnyk I. M. Identification of electrical parameters of powerful short-circuit laminated packs, Electrical Engineering and Power Engineering, 2012, No. 2, pp. 55-61. doi: http://dx.doi.org/10.15588/16076761-2012-2-10

10. Yarymbash D. S. Identification of furnace loop electrical parameters of power graphitization furnaces, Electrical engineering \& Electromechanics, 2012, No. 1, pp. 49-54.

11. Yarymbash D., Kotsur M., Subbotin S., Oliinyk A. Anew simulation approach of the electromagnetic fields in electrical machines, IEEE: The International Conference on Information and Digital Technologies, 2017. Slovakia, Zilina, pp. 452-457. DOI: 10.1109/ DT.2017.8024332.

12. Aliferov A. I., Bikeev R. A., Goreva L. P. et al. Experience and modern technology of the ore-thermal furnace short network designing, 11 International forum on strategic technology (IFOST 2016) : proc., Novosibirsk, 1-3 June 2016. Novosibirsk, NSTU, 2016, Pt. 2, pp. 124-126. ISBN 978-1-5090-0853-7. DOI: 10.1109/IFOST.2016.7884207

13. Serikov V., Vlasov D., Goreva L. et al. Active power losses in pressure rings for contact shoes of ore-thermal furnace, Applied Mechanics and Materials, 2015, Vol. 698 : Electrical Engineering, Energy, Mechanical Engineering, EEM 2014, pp. 57-60. DOI: 10.4028/www.scientific.net/AMM.698.57

14. Goreva L., Vlasov D., Shvetsova M. S. Investigation of electrical parameters of interleaved conductors' packages in high power electrotechnological installations, Applied Mechanics and Materials, 2015, Vol. 792 : Electrical Engineering, Electrotechnology, Energy, EEE 2015, pp. 495-498. DOI: 10.4028/www.scientific.net/AMM.792.495

15. Aliferov A. I., Goreva L. P., Bikeev R. A. et al. Ore-thermal furnaces secondary circuit parameters optimization, The 8 
international forum on strategic technologies (IFOST 2013) : proc., Mongolia, Ulaanbaatar, 28 June-1 July 2013, Ulaanbaatar, 2013, Vol. 1, pp. 283-285. DOI: 10.4028/ www.scientific.net/AMM.698.35.

16. Aliferov A. I., Bikeev R. A., Vlasov D. S. et al. Ferromagnetic conductors electric resistances investigation under electrocontact heating, International conference on heating by electromagnetic sources, HES-2013: induction, dielectric and microwaves, conduction \& electromagnetic processing : [proc.], Italy, Padua, 21-24 May, 2013, Padua, 2013, pp. 457-461.

17. Montanari G.G., Loggini M., Cavallini A. et al. Arc-Furnace model for the study of Flicker Compensation in Electrical Networks, IEEE Transactions on Power Delivery, 1994, Vol. 9, No. 4, pp. 2026-2036. DOI: 10.1109/61.329535.

18. Jang G., Wang W., Heydt G.I. et al. Development of Enhanced Electric Arc Furnace Models for Transient Analysis, Electric Power Components and Systems, 2001, Vol. 29, No. 11, pp. $1060-$ 1073. DOI: $10.1080 / 153250001753239257$.

19. Panoiu M., Panoiu C., Sora I. Experimental Research Concerning the Electromagnetic Pollution Generated by the 3-Phase Electric Power Supply Networks, Acta Electrotehnica, 2006, Vol. 47, No. 2, pp. 102-112.

20. Zaprjagaev S. A. Jelektrodinamika. Voronezh, Izd-vo Voronezh. gos. un-ta, 2005, $536 \mathrm{p}$.

21. Il'inskij A. S., Kravcov V. V., Sveshnikov A. G. Matematicheskie modeli jelektrodinamiki. Moscow, Vysshaja shkola, 1991, 222 p.

22. Taflove A., Hagness S. C. Computational Electrodynamics: The Finite-difference Time-domain Method, Artech House, 2005, 852 p. ISBN 978-1-58053-832-9.

23. Amosov A. A. Vychislitel'nye metody dlja inzhenerov. Moscow, Jenergija, 1994, 284 p.
24. Rojak M. Je., Solovejchik Ju. G., Shurina Je. P. Setochnye metody reshenija kraevyh zadach matematicheskoj fiziki. Novosibirsk, Izd-vo NGTU, 1998, $120 \mathrm{p}$.

25. Koshljakov N. S., Gliner Je. B., Smirnov M. M. Uravnenija v chastnyh proizvodnyh matematicheskoj fiziki. Moscow, Vysshaja shkola, 1970, $710 \mathrm{p}$

26. Samarskij A. A., Gulin V. A. Chislennye metody. Moscow, Nauka, 1989, $430 \mathrm{p}$.

27. Abaffi J., Spedikato Je. Matematicheskie metody dlja reshenija linejnyh i nelinejnyh uravnenij. Moscow, Jenergija, 1996, 287 p.

28. Yee K. S. Numerical solution of initial boundary value problems involving Maxwell's equations in isotropic media, IEEE Trans. Antennas Propagat, 1996, Vol. 14, pp. 302-307. DOI: 10.1109/ tap.1966.1138693.

29. Glazunov Ju. T. Variacionnye metody. Moscow, Reguljarnaja i haoticheskaja dinamika, Institut komp'juternyh issledovanij, 2006, 472 p.

30. Nikol'skij V. V. Variacionnye metody dlja vnutrennih zadach jelektrodinamiki. Moscow, Nauka, 1967, 460 p.

31. Rektoris K. Variacionnye metody $\mathrm{v}$ matematicheskoj fizike $\mathrm{i}$ tehnike. Moscow, Mir, 1985, 589 p.

32. Brebbija K., Telles Zh., Vroubel L. Metody granichnyh jelementov. Moscow, Mir, 1987, 524 p.

33. Laevskij Ju. M. Metod konechnyh jelementov (osnovy teorii, zadachi). Novosibirsk, Novosib. gos. un-t, 1999, 166 p.

34. Streng G., Fiks Dzh. Teorija metoda konechnyh jelementov. Moscow, Mir, 1977, 350 p.

35. Astahov V. I. Matematicheskoe modelirovanie inzhenernyh zadach v jelektrotehnike. Novocherkassk, NGTU, 1994, 192 p.

36. Samarskij A. A. Vvedenie v chislennye metody. Sank Peterbug, Izdatel'stvo "Lan", 2005, 288 p.

37. Babenko K. I. Osnovy chislennogo analiza. Moscow, Nauka, 1986, $374 \mathrm{p}$ 